\title{
The Effect of Budgetary Participation, Organizational Commitment, and Leadership Styles on the Employees' Performance
}

Mila Purani Sistiyan ${ }^{1}$

Palikhatun

Payamta

Received 2019-01-10

Accepted 2019-01-11

Published 2019-01-11

Keywords

Budgetary participation,

Organizational commitment,

Leadership styles,

Employees' performance

How to cite?

Sistiyan, M., Palikhatun, P., \&

Payamta, P. (2019). The Effect of

Budgetary Participation, Organizational

Commitment, and Leadership Styles on

the Employees' Performance.

SEISENSE Journal of Management,

2(1), 107-117.

bttps:// doi.org/10.33215/sjom.v2i1.97

Copyright (c) 2019 The Author(s)

\section{(cc) BY}

Master Program of Accounting, Faculty of Economics and Business, Universitas Sebelas Maret, Indonesia

Master Program of Accounting, Faculty of Economics and Business, Universitas Sebelas Maret, Indonesia

Master Program of Accounting, Faculty of Economics and Business, Universitas Sebelas Maret, Indonesia

${ }^{1}$ Corresponding author's email address: milapurani@staff.uns.ac.id 


\section{Introduction}

The state civil apparatuses are expected to have sufficient abilities, expertise, and professionalism in order to be able to carry out their jobs properly. The employees' performance becomes one of the keys to the success of a governmental agency either directly or indirectly through their contribution to the agency for the sake of achieving the goals set by the agency. One of the means of improving the employees' performance in an agency is by engaging the employees in the process of budget preparation.

The state budget is a series of processes taking place in decision making vis-a-vis the governmental actions which are going to be enacted, and how a resource will be allocated, economized, and utilized to achieve the goals. Setting the goals of an organization is expected to capably increase the employees' performance. With the presence of a number of goals to be reached, it will lead someone to focus on affording to achieve the given goals through making an effort and applying some strategies (Miller \& Monge, 1986). On account of the employees' participation in the preparation of the budget, it is hoped to manage to enhance the employees' performance. When the goals and the standards which are participatory set have been appropriately agreed, the employees will have a sense of being in charge of the demand for achieving those goals and standards due to the feeling of getting involved in the preparation of budget (Milani, 1975).

The participation in budget preparation has been numerously studied in the realm of private sectors, and among the studies are those conducted by Brownell (1981, 1982); Brownell and McInnes (1986); Chenhall and Brownell (1988); and Nouri and Parker (1998). In their study, Chong and Chong (2002) mention that if subordinates, or in other words employees, are incorporated in a decision-making process, it will strengthen their commitment to achieving the goals. Latham and Yuki (1976); and Milani (1975) opine that the improvement of performance will become greater through setting the goals participatory if compared to doing it without any participation of the subordinates or employees. Gul et al. (1995); and Bruns et al. (1975) have revealed that the budgetary participation will have a positive impact on the performance in an organization whose delegation of authority is relatively decentralized.

The studies conducted by Nor (2007); and Yanida et al. (2013) find out that the participation in budget preparation has a positive correlation with the performance of the state apparatuses. In addition, the studies undertaken by Brownell (1982); Brownell and McInnes (1986); Frucot and Shearon (1991); Wagner (1994); Chong and Wing (2003); Frucot and White (2006); and Lopez, et al. (2007) attest to a positive and significant correlation between the participation in budget preparation and the managerial performance. On the other hand, the studies conducted by Cherrington and Cherrington (1973); Milani (1975); Kenis (1979); and Brownell and Hirst (1986) have a contrary result whereby those studies manifest in an insignificant relationship between the participation in budget preparation and the managerial performance. Furthermore, the studies carried out by Bryan and Locke (1967); Stedry (1960); and Sulistyowati and Kiryanto (2006) even indicate that the participation in budget preparation has a negative impact on the managerial performance.

Another point affecting the employees' performance is the commitment to the organization. The commitment to an organization per se becomes a sort of motivation in one's self for doing something so that he/she manages to support the organization to thrive on realizing the visions, missions, and goals set by the organization as well as to prioritize the organization interests. According to Khan et al. (2010), a high commitment to an organization will result in high performance as well. Someone's high commitment to an organization will motivate him/her to achieve the organization goals, and such motivation will, later on, enhance his/her performance.

The studies conducted by Putti, et al. (1990); Chen and Francesco (2003); Khan et al. (2010); and Memari et al. (2013) examine the correlation between a commitment to an organization and the employees' performance in private sectors. The results of their studies prove that a commitment as such has a positive effect on the 
employees' performance in private sectors. On the other hand, the study result garnered by Mathieu and Zajac (1990); and Somers and Birnbaum (1998) show that a commitment does not have any correlation with the employees' performance. Wright (1997) found a negative relationship between organizational commitment and employee performance.

Leadership also obviously influences someone's (in this sense an employee) performance in an agency or organization. The success of an agency in achieving its goals is one of them, determined by the quality of leadership. A leader in an organization will anticipate any changes, properly make use of any chances, motivate the employees, evaluate the employee's performance, and support to achieve the organization goals. A leader can exert his/her authority to change the employees' attitude and behavior in order for them to be willing to industriously make an effort to reach the optimal results. The presence of a leader's motivation or encouragement will promote the enhancement of an employee's performance.

In accordance with Lewin et al. (1939), there are three styles of leadership commonly applied in an organization in order to guide the employees to achieve the organization goals. They are known by authoritarian leadership, democratic leadership, and laissez-faire, or in the other term, delegative leadership. The style of authoritarian leadership draws on a leader who inclines to centralize the authority on himself/herself. He/she will dictate how every single task should be accomplished, make a decision unilaterally by himself/herself, and minimalize the employees' participation. The style of democratic leadership portrays a leader who tends to incorporate the employees into decision making, to delegate his/her authority, to encourage the employees' participation in determining the appropriate methods which conceivably work as well as the goals which will be achieved, and to discern that feedback is a kind of an opportunity to train the employees. Subsequently, the style of laissez-faire leadership depicts a leader who in overall gives the employees a sort of free will in making certain decisions and accomplishing the tasks on the basis of the conformity to the employees' perspectives.

The existence of inconsistency found in the previous studies which examine the influence of leadership styles and performance becomes the basis underpinning the present study. For instance, among the aforementioned studies are those conducted by Adeyemi (2010); and Belonio (2012) in which they find out that the style of authoritarian leadership has a significant impact on the employees' performance, while those undertaken by Dolatabadi and Safa (2010); and Obiwuru et al. (2011) prove that the style of authoritarian leadership does not have any impact on the employees' performance. In addition, the studies done by Belonio (2011); Umer et al. (2012); and Mawoli and Mohammed (2013) show a significant effect of a democratic leadership style on the employees' performance, whereas the study carried out by Malcalm and Tamatey (2017) reveals that the styles of both authoritarian and laisser-faire (delegative) leadership do not significantly affect the employees' performance.

Based on the study undertaken by Soleman (2012), the style of leadership and the culture prevailing in an organization become the intervening variables between participatory budgeting and the managerial performance. In addition, Memon (2014) examines the effect of leadership styles on the employees' performance by assigning culture as well as gender as the mediator variables and communication as the moderator variable. Furthermore, Mohammed et al. (2014) scrutinize the correlation between the leadership styles and the employees' performance in private sectors.

This study engages the samples comprised of the employees from the work units under the state treasury service office (in the Indonesian language commonly known by Kantor Pelayanan Perbendaharaan Negara and generally abbreviated as KPPN) of Surakarta. The rationale behind selecting them as the samples is because during 2015 up to 2017 the KPPN of Surakarta steadily gained a good rank with respect to the performance management, the preparation of the procurement policy agency of governmental goods / services (in 
Indonesian language commonly known by Lembaga Kebijakan Pengadaan Barang / Jasa Pemerintah and generally abbreviated as LKPP), and the performance evaluation of budget execution. Grounded in the abovementioned elaboration, this study is conducted to scrutinize the effect of budgetary participation, organizational commitment, and the styles of leadership on the employees' performance.

\section{Literature Review}

\section{Budgetary Participation}

According to Kennis (1979), budgetary participation is the involvement degree of the central manager of accountability in compiling and influencing the budget at the center of accountability under his/her supervision. As explained by Milani (1975), budgetary participation refers to the degree of someone's influence and engagement in the process of budgeting which has a range of characteristics that entail the engagement in budgeting, satisfaction in budgeting, the needs to give opinions, willingness to express opinions, and the magnitude of influence on the setting of final budget.

\section{Organizational Commitment}

Organizational commitment portrays someone's conviction, support, and loyalty to the values and objectives which are expected to be achieved by the organization (Mowday et al., 1979). According to Triatna (2015), organizational commitment is a condition whereby an employee espouses an organization along with its goals and is voluntarily willing to maintain his/her membership in that organization. A strong organizational commitment will lead an individual to make a serious effort to achieve the organizational goals or objectives, to think positively, and to strive to do the best for the organization.

\section{Leadership Style}

The style of leadership is a sort of process whereby someone manages to lead, guide, and direct as well as influence other people's thoughts and behaviors for the sake of achieving a particular goal. Leadership can support the achievement of organizational goals by means of influencing other people (Mawoli, 2013). Anchored in Lewin et al. (1939), there are three styles of leadership which are generally applied in an organization. They are as the following details:

The style of authoritarian leadership: It refers to a leadership style which exerts the method of power approach in making a decision and developing further structures of an organization. Hence, the power is benefited in the organization.

The style of democratic leadership: It draws on a leader who inclines to involve the employees in making decisions, to delegate his/her authority, to encourage the employees' participation while determining the appropriate methods that work as well as setting the organizational goals, and to discern that feedback becomes a kind of an opportunity to train the employees.

The style of Laissez-faire leadership: It depicts a leader who in overall gives his/her employees or groups free will to make decisions and accomplish tasks on the basis of the conformity to the employees' perspectives.

\section{Employees' Performance}

In accordance with Sedarmayanti (2009), performance is a work result which can be achieved by an individual or a group of people in an organization, in which the work result is compatible with respective authorities and responsibilities for legally achieving the organizational goals. The work result per se does not violate the law, and it should do justice to morals and ethics. In addition, Hasibuan (2010) postulates that performance is a work result achieved by someone in doing the tasks assigned to him/her based on his/her experiences, 
excellence, and time. Mondy, Noe, and Premeaux (1999) state that performance measurement can be done using a couple of dimensions that include the quantity of work, the quality of work, dependability, initiative, adaptability, and cooperation.

\section{The Effect of Budgetary Participation on the Managerial Performance}

With participating in the preparation of the budget, the employees will feel getting involved and being in charge of the budget execution so that it is expected that the employees are able to prepare the budget better. Thus, the company's goals can be well-achieved. The studies executed by Nor (2007), and Yanida et al. (2013) find out that budgetary participation has a positive correlation with the state apparatus performance. In addition, the studies undertaken by Brownell (1982); Brownell and McInnes (1986); Frucot and Shearon (1991); Wagner (1994); Chong and Wing (2003); Frucot and White (2006); and Lopez, et al. (2007) show a positive and significant correlation between the budgetary participation and the managerial performance. Subsequently, Latham and Yuki (1976); and Milani (1975) opine that the improvement of performance will be greater through participatory setting the goals instead of doing it without any participation. As regards the aforementioned explanation, the following hypothesis is formulated:

Hypothesis 1: There is a positive effect of budgetary participation on the employees' performance.

\section{The Effect of Organizational Commitment on the Managerial Performance}

According to Khan et al. (2010), a high organizational commitment will generate a high performance either. Someone's high commitment to an organization will promote the success in achieving the organization goals, and such commitment will, later on, improve his/her performance. The committed governmental employees will work maximally inasmuch as they look forward to the success of the organization where they are working with. Such a condition will yield the improvement of their performance since they have a conviction that the government's visions and missions will be realized along with their contributions. To view further in a relatively similar issue, the studies conducted by Putti, et al. (1990); Chen and Francesco (2003); Khan et al. (2010); and Memari et al. (2013) that examine the correlation between organizational commitment and the employees' performance in private sectors show that organizational commitment has a positive influence on the employees' performance in those private sectors. Associated with the abovementioned explanation, the following hypothesis is formulated:

Hypothesis 2: There is a positive effect of the organizational commitment on the employees' performance.

\section{The Effect of Leadership Styles on the Employees' Performance}

A leadership factor plays an important role in improving the employees' performance because an effective leadership will give encouragements to reach the organizational goals. The styles of leadership per se are needed by any leader in order to capably enhance the performance of all of his/her employees for the sake of achieving the goals of an organization as the public service agency. Accordingly, the styles of leadership can become an appropriate resource for improving the employees' performance. As categorized by Lewin et al (1939), there are generally three styles of leadership. They encompass the authoritarian, democratic, and laissez-faire leadership.

Adeyemi (2010); and Belonio (2012) find out that an authoritarian leadership style has a significant effect on the employees' performance. Continuously, the studies executed by Belonio (2011); Umer et al. (2012); and Mawoli and Mohammed (2013) manifest that there is a significant influence of a democratic leadership style on the employees' performance. In a relatively similar orientation, Memon (2014) scrutinizes the effect of leadership styles on the employees' performance by utilizing culture as well as gender as the mediator variables and communication as the moderator variable. Furthermore, Mohammed et al. (2014) examine the 
correlation between leadership styles and the employees' performance in private sectors. Subsequently, the study carried out by Brownell and McInnes (1986) indicates that the style of leadership vis-a-vis the system of budgeting has an impact on the employees' performance. With regard to the preceding elaborations, the following three hypotheses are then formulated:

Hypothesis 3a: There is a positive effect of an authoritarian leadership style on the employees' performance.

Hypothesis 3b: There is a positive effect of a democratic leadership style on the employees' performance.

Hypothesis 3c: There is a positive effect of a laissez-faire leadership style on the employees' performance.

\section{Method}

This study utilized primary data. The primary data were garnered from carrying out a survey to the employees of the state ministry/institution (in an Indonesian term commonly abbreviated as $K / L$ ) work units in the state treasury service office (in an Indonesian term commonly abbreviated as KPPN) of Surakarta working area. There were 80 work units incorporated into this study. The samples of this study entailed the employees from the work units under the KPPN of Surakarta working area. The following is the list of work units along with the budget ceiling. The selection of samples in this study used a purposive sampling method with the criteria comprising the employees directly engaged in the preparation of budget, those having qualified abilities in information technology in association with the operationalization of budgeting execution, and those having a two-year minimum work period within KPPN work units which included a couple of regions such as Surakarta, Sukoharjo, and Wonogiri, whereby a total of 80 work units, those under both ministry and institution, were incorporated. The questionnaire was directly given to the respondents who came to submit a payment order (in an Indonesian term abbreviated as SPM) or to reconcile the financial reports to the KPPN of Surakarta.

The measurement items of the budgetary participation variable referred to Milani's (1975) study exerting the measurement items of organizational commitment using OCQ (the Organizational Commitment Questionnaire) as cited in Mowday et al. (1979). There were totally nine items of questions which were assigned. The variable of leadership styles was measured based on the instrument constructed by Mawoli and Mohammed (2013). Subsequently, the variable appertaining to the employees' performance was measured by using the instrument developed by Tsui et al. (1997). All of those variables were measured using Likert scale containing 7 points. The primary data obtained in this study were analyzed using a variety of statistical tests. The data analyses were undertaken not only to test the hypotheses but also to examine other statistical calculations such as validity test, reliability test, and classic assumption tests which subsumed normality, heteroscedasticity, autocorrelation, and multicollinearity test.

\section{Results and Discussion}

The respondents in this study referred to the employees directly involved in the preparation of budget within the work units of KPPN which subsumed a few regions such as Surakarta, Sukoharjo, and Wonogiri, whereby 80 work units under both ministry and institution were involved. Of 165 questionnaires which were distributed, 116 pieces were returned and could further be analyzed.

The validity test was undertaken by employing Pearson's Product Moment method, and the result manifested that the questionnaire items pertinent to the variables which entailed budgetary participation, organizational commitment, the authoritarian, democratic, as well as laissez-faire leadership styles, and the employees' performance were all valid. The reliability test was executed by calculating Cronbach's coefficient alpha. In this regard, the more proximate the Cronbach's alpha to number one is, the higher the reliability of variables will be (Sekaran, 2000). The variables can be said reliable if the value of Cronbach's alpha is higher than 0.6 (Nunnally 
in Ghozali, 2006). In this study, the result of a reliability test showed that the value of Cronbach's alpha exceeded 0.6.

The classic assumption tests fell into some categories: normality, heteroscedasticity, autocorrelation, and multicollinearity test. The method applied for normality test was Kolmogorov-Smirnov, and the result showed that all regressions were normally distributed on account of the value of significance exceeding 0.005 . The method exerted to execute heteroscedasticity test was scatterplot, and the result indicated that no certain patterns which, for instance, became (wavy, widened, and then narrowed) were orderly formed, so such condition inferred that there was no the occurrence of heteroscedasticity. Subsequently, the autocorrelation test assigned run test by initially forming a residual variable, and the result manifested that the value of the regression run test was -0.933 along with the significance level as high as 0.351 which exceeded 0.05 , so it could be concluded that autocorrelation did not occur to the regression model. The multicollinearity test was done by viewing the values of tolerance and Variance Inflation Factor (VIF). The calculation result of tolerance in the multiple regression showed that all of the independent variables had the tolerance value exceeding 0.10 , wherein it meant that there was no correlation among the independent variables. The calculation of $V$ ariance Inflation Factor (VIF) also attested, whereby all independent variables had the value of VIF less than 10. Hence, it could be concluded that multicollinearity did not occur among the independent variables.

The hypotheses in this study were tested using the multiple regression analyses which applied the following formula:

$$
\begin{array}{lll}
\mathrm{Y} & = & \mathrm{a}+\mathrm{b}_{1} \cdot \mathrm{X}_{1}+\mathrm{b}_{2} \cdot \mathrm{X}_{2}+\mathrm{b}_{3} \cdot \mathrm{X}_{3}+\mathrm{b}_{4} \cdot \mathrm{X}_{4}+\mathrm{b}_{5} \cdot \mathrm{X}_{5}+\mathrm{e} \\
\mathrm{Y} & = & \text { employees' performance, } \\
\mathrm{a} & = & \text { Constant, } \\
\mathrm{b}_{1}, \mathrm{~b}_{2}, \mathrm{~b}_{3}, \mathrm{~b}_{4}, \mathrm{~b}_{5}= & \quad \text { regression coefficient, } \\
\mathrm{X}_{1}= & \text { Budgetary participation, } \\
\mathrm{X}_{2}= & \text { Organizational commitment, } \\
\mathrm{X}_{3}= & \text { Authoritarian leadership styles, } \\
\mathrm{X}_{4}= & \text { Democratic leadership styles, } \\
\mathrm{X}_{5}= & \text { Laissez-faire leadership styles, } \\
\mathrm{e} & = & \text { Residual error. }
\end{array}
$$

The results of multiple regression analyses are shown in the following table:

Table 1 - Regression Analysis

\begin{tabular}{lcccc}
\hline Variable & B & Std. Error & t & sig. \\
\hline Constant & 2.428 & 2.456 & 0.989 & 0.325 \\
Budgetary participation & 0.417 & 0.145 & 2.873 & 0.005 \\
Organizational commitment & 0.471 & 0.111 & 4.243 & 0.000 \\
Authoritarian leadership styles & 0.112 & 0.119 & 0.936 & 0.351 \\
Democratic leadership styles & 0.296 & 0.114 & 2.586 & 0.011 \\
Laissez-faire leadership styles & -0.020 & 0.180 & -0.111 & 0.912 \\
\hline $\mathrm{N}=116$ & & $\mathrm{~F}=74.047$ & \\
Adj. $\mathrm{R}^{2}=0,761$ & & Sig. F = 0.000 & \\
\hline
\end{tabular}


The model of multiple regression could be used to predict the employees' performance because it had the value of Sig. F less than 0.05 (0.000). Adjusted $\mathrm{R}^{2}$ which reached 0.761 meant that $76.1 \%$ of the employees' performance variance was caused by the independent variables that were comprised of budgetary participation, organizational commitment, and leadership styles. The analysis of each hypothesis can be seen as follows:

The significance value, $\mathrm{t}(0.005)$, for the independent variable referring to budgetary participation in the multiple regression as displayed above was evidently significant because the value was less than 0.05 . The multiple regression analysis which was done resulted in the coefficient as high as 0.417 meaning that the budgetary participation had a significant and positive effect on the employees' performance. This condition at once supported the first hypothesis stating that there is a positive effect of budgetary participation on the employees' performance. Such support to the first hypothesis is also consistent with the results of studies conducted by Brownell (1982); Brownell and McInnes (1986); Frucot and Shearon (1991); Wagner (1994); Chong and Wing (2003); Frucot and White (2006); and Lopez, et al. (2007).

The significance value of $\mathrm{t}$ in the multiple regression indicated that the independent variable as regards organizational commitment significantly affected the employees' performance since the value, 0.000 , was less than 0.05. The multiple regression analysis which was done resulted in the coefficient as high as 0.471 meaning that the organizational commitment had a significant and positive effect on the employees' performance. The testing result of this second hypothesis proved that an employee's performance was affected by his commitment to the agency where he was working in. Such agreement to this second hypothesis is also shown by a couple of studies such as those of Putti, et al. (1990); Chen and Francesco (2003); Khan et al. (2010); and Memari et al. (2013).

The regression result of the authoritarian leadership style variable to the employees' performance had the significance value of $\mathrm{t}(0,351)$, so the hypothesis $3 \mathrm{a}$ accentuating that there is a positive effect of an authoritarian leadership style on the employees' performance was not proven. This study result consistently aligns with the studies carried out by Mawoli and Mohammed (2013); and Malcalm and Tamatey (2017).

The significance value of $\mathrm{t}$ in the multiple regression indicated that the independent variable with respect to the democratic leadership style evidently had a significant effect on the employees' performance because the value, 0.011 , was less than 0.05 . The multiple regression analysis which was done resulted in the coefficient as high as 0.296 meaning that the democratic leadership style had a significant and positive effect on the employees' performance. In this regard, the conformity to the second hypothesis is also in line with the results of studies executed by Belonio (2011); Umer et al. (2012); and Mawoli and Mohammed (2013).

The significance value of t (0.912) for the laissez-faire leadership style variable, as displayed above, did not affect the employees' performance because the value exceeded 0.05. Accordingly, the hypothesis $3 \mathrm{c}$ stating that there is a positive effect of laissez-faire (delegative) leadership style on the employees' performance was not proven. This result conforms to the results of studies conducted by Mawoli and Mohammed (2013); and Malcalm and Tamatey (2017).

\section{Conclusion}

The results of multiple regression analyses support the hypotheses which emphasize that budgetary participation, organizational commitment, and one of the leadership styles (the democratic leadership style) have a positive effect on the employees' performance. Nonetheless, the results of multiple regression analyses for the authoritarian and laissez-faire leadership styles do not support the hypotheses, wherein both authoritarian and laissez-faire leadership styles do not affect the employees' performance. 


\section{References}

Adeyemi, TO. (2010). Principals' Leadership Styles and Teachers' Job Performance in Senior Secondary Schools in Ondo State, Nigeria. Journal of Education Administration and Policy Studies, 2(6), 8391.

Belonio, Rochelle. (2012). The Effect of Leadership Style on Employee Satisfaction and Performance of Bank Employee on Bangkok. Assumption University Graduate School of Business Journal, 5(2), 111-116.

Brownell \& McInnes. (1986). Budgetary Participation, Motivation, and Managerial Performance. The Accounting Review, 587-600.

Brownell P \& Hirst M. (1986). Reliance on Accounting Information, Budgetary Participation, and Task Uncertainty. Journal of Accounting Research, 24, 241-249.

Brownell, P. (1981). Participation in Budgeting, Locus of Control, and Organization Effectiveness. The Accounting Review, 844-860.

Brownell, P. (1982). Participation in Budgeting Process: When it Works and When it doesn't. Journal of Accounting Literatur) 124-153.

Bruns W, Bruns Jr. \& Waterhouse JH. (1975). Budgetary Control and Organization Structure. Journal of Accounting Research, vol. 13(2), 177-203.

Bryan JF \& Locke EA. (1967). Goal setting as a means of increasing motivation. Journal of Applied Psychology, June, 274-277.

Chen ZX \& Francesco AM. (2003). The Relationship between the Three Components of Commitment and Employee Performance in China. Journal of Vocational Behavior, 62, 490-510.

Chenhall, R.H. dan Brownell, P. (1988). The Effect of Participative Budgeting on Job Satisfaction and Performance: Role Ambiguity as an Intervening Variable. Accounting, Organization, and Society, 225-233.

Cherrington DJ dan Cherrington JO. (1973). Appropriate Reinforcement Contingencies in the Budgeting Process. Journal of Accounting Research, 225-253.

Chong, VK \& Wing SLT. (2003). Testing a model of the motivational role of budgetary participation on job performance: a goal setting theory analysis, Asia Review of Accounting, 11(1), 1-17.

Chong VK \& Chong KM. (2002). Budget Goal commitment and Informational Effects of Budget Participation on Performance: A Structural Equation Modeling Approach. Behavioral Research in Accounting, 14, 67-68.

Dolatabadi, HR \& Safa, M. (2010). The Effect of Directive and Participatory Leadership Style on Employees' Commitment to Service Quality. International Bulletin of Business Administration, Issue 9, 31-42.

Frucot, V \& Shearon, WT. (1991). Budgetary Participation, Locus of Control, and Mexican Managerial Performance and Job Satisfaction. The Accounting Review, 66(1), 80-99.

Ghozali, Imam. (2006). Aplikasi Analisis Multivariate dengan Program SPSS. Semarang: Badan Penerbit Universitas Diponegoro.

Gul FA, Tsui JSL, Steve C, Fong C \& Kwok HYL. (1995). Decentralization as a Moderating Factor in the Budgetary Participation Performance Relationship: Some Hongkong Evidence. Accounting and Business Research, 25(98), 107-113.

Hasibuan, Malayu S.P. (2010). Manajemen Sumber Daya Manusia. Jakarta: BumiAksara.

Kenis, I. (1979). Effects of Budgetary Goal Characteristics on Managerial Attitudes and Performance. The Accounting Review, 707-721.

Khan MR, Ziauddin, Jam FA \& Ramay MI. (2010). The Impact of Organizational Commitment on Employee Job Performance. European Journal of Social Sciences, 15(3), 292-298. 
Latham GP \& Yuki GA. (1976). Effects of Assigned and Participative Goal Setting on Performance and Job Satisfaction. Journal of Applied Psychology, 61(2), 166-171.

Lewin K, Lippit R \& White RK. (1939). Patterns of Aggressive Behavior in Artificially Created Social Change. Journal of Social Psychology, 10, 271-299.

Lopez Maria A. Leach, William W. Stammerjohan, Frances M. McNair. (2007). Differences in the role of job-relevant information in the budget participation performance relationship among U.S. and Mexican Managers: A Question of culture or communication. Journal of Management accounting research, 19, 105-136

Malcalm, E. \& Tamatey, S. (2017). Examining Leadership Style on Employee Performance in The Public Sector Of Ghana: A Case of Ghana Atomic Energy Commission. International Journal of Scientific and Research Publications, 7(11), 343-361.

Managerial Performance and Job Satisfaction. The Accounting Review, 66(1), 80-99

Mathieu JE \& Zajac DM. (1990). A Review and Meta-Analysis of the Antecedents, Correlates, and Consequences of Organizational Commitment. Psychology Bulletin, 108, 171-194.

Mawoli, Mohammed Abubakar \& Mohammed, Tanimu Haruna. (2013). Effect of Leadership Styles on Employees' Job Performance: Evidence from Federal Medical Centre in Niger State. Journal of Management Science, 4(1), 28-38.

Memari N, Mahdieh O \& Marnani AB. (2013). The Impact of Organizational Commitment on Employees' Job Performance A Study of Meli Bank. Interdisciplinary Journal of Contemporary Research in Business, 5(5), 164-171.

Memon, Khalid Rasheed. (2014). Effects of Leadership Styles on Employee Performance: Integrating the Mediating Role of Culture, Gender, and Moderating Role of Communication. International Journal of Management Sciences and Business Research, 3(7), 63-80.

Milani, Ken. (1975). The Relationship of Participation in Budget Setting to Industrial Supervisor Performance and Attitudes: A Field Study. The Accounting Review, 50(2), 274-284.

Miller KI \& Monge PR. (1986). Participation, Satisfaction and Productivity: A Meta-Analytical Review. Academy of Management Journal, 29(4), 727-753.

Mohammed, UD, Yusuf, MO, Sanni IM, Ifeyinwa TN, Bature NU, dan Kazeem, AO. (2014). The Relationship between Leadership Styles and Employees' Performance in Organizations (A Study of Selected Business Organizations in Federal Capital Territory, Abuja Nigeria. European Journal of Business and Management, 6(22), 1-11.

Mondy, W., Noe, M. and Premeaux, R. (1999). Human Resource Management. 7th Edition, London: Prentice-Hall International.

Mowday, RT, Steers RM, \& Porter LW. (1979). The Measurement of Organizational Commitment. Journal of Vocational Behavior, 14, 224-247.

Nor, W. (2007). Desentralisasi dan Gaya Kepemimpinan sebagai Variabel Moderating dalam Hubungan Antara Partisipasi Penyusunan Anggaran dan Kinerja Manajerial. Simposium Nasional Akuntansi X, 1-27.

Nouri H \& Parker RJ. (1998). The Relationship between Budget Participation and Job Performance: The Roles of Budget Adequacy and Organizational Commitment. Accounting, Organizations and Society, 23(5-6), 467-483.

Obiwuru, TC, Okwu AT, Akpa VO \& Nwankwere IO. (2011). Effects of Leadership on Organizational Performance: A Survey of Selected Small Scale Enterprises in Ikosi-Ketu Council Area of Lagos State, Nigeria. Australian Journal of Business and Management Research, 1(7), 100-111.

Putti, JM, Aryee, S, \& Phua, J. (1990). Communication relationship satisfaction and organizational commitment. Group \& Organization Studies, 15(1), 44-52. 
Sedarmayanti, (2009). Sumber Daya Manusia dan Produktivitas Kerja. Bandung: Mandar Maju

Sekaran, Uma. (2006). Research Methods for Business. New York: John Wiley \& Sons Inc.

Somers MJ \& Birnbaum D. (1998). Work-Related Commitment and Job Performance: It's also the Nature of the Performance That Counts. Journal of Organizational Behavior, 19(6), 621-634.

Stedry, A.C. (1960). Budget Control and Cost Behavior. Englewood Cliffs, Nj: Prentice Hall.

Sulistyowati \& Kiryanto. (2006). Pengaruh Motivasi dan Pelimpahan Wewenang Serta Sistem Penghargaan Terhadap Hubungan Antara Partisipasi Penyusunan Anggaran Dengan Kinerja Manajerial. Jurnal Akuntansi Indonesia, 2(3).

Triatna, Cepi. (2015). Perilaku Organisasi. Bandung: PT.Remaja Rosdakarya.

Tsui, AS, Pearce J., Porter LW \& Tripoli AM. (1997). Alternative Approaches to the EmployeeOrganization Relationship: Does Investment in Employees Pay Off? The Academy of Management Journal, 40(5), 1089-1121

Umer, P, Adnan Q, Anam M \& Inam-ul-Hassan W. (2012). Impact of Leadership Styles (Transformational \& Transactional Leadership) on Employee Performance and Mediating Role of Job Satisfaction: Study of Private School (Educator) In Pakistan, Global Journal of Management and Business Research, 12(4), version 1.0

Wagner III. John A. (1994), Participation's Effects on Performance and Satisfaction a Reconsideration of Research Evidence, Academy of Management Review, 19(2), 312-330.

Wright, TA. (1997). Job performance and organizational commitment. Perceptual and Motor Skills, vol. $85(2), 447-450$.

Yanida M, Sudarma M, \& Rahman AF. (2013). Pengaruh Partisipasi Anggaran terhadap Kinerja Aparatur Pemerintah. Jurnal Akuntansi Multiparadigma, 4(3), 330-357. 